\title{
Clinical features of oral cavity of patients with non-Hodgkin's lymphoma undergoing chemotherapy
}

\author{
Diptakanya Murdi Suroso*, Tenny Setiani Dewi*, Trinugroho Heri Fadjari** \\ *Department of Oral Medicine Faculty of Dentistry Universitas Padjadjaran, Indonesia \\ ${ }^{* *}$ Department of Internal Medicine Faculty of Medicine Universitas Padjadjaran, Indonesia
}

\section{ABSTRACT}

Introduction: Non-Hodgkin's lymphoma is one of hematologic malignancy that responds to chemotherapy. Chemotherapy agent can cause oral complication such as oral mucositis, hemorrhage, xerostomia, hyposalivation and periodontitist. The purpose of this study is to determine the clinical feature of the oral cavity in patients with non-Hodgkin's lymphoma whose underwent chemotherapy Method: This study used an observational descriptive method. This type of research is observational descriptive. The study population was non-Hodgkin's lymphoma sufferers who were undergoing chemotherapy at the Hematology and Medical Oncology Outpatient Installation Division of Internal Medicine at Hasan Sadikin Hospital Bandung. The study sample was taken by consecutive sampling method The numbers of samples in this study were 30 people according to predetermined criteria. Result: The result shows that all samples have abnormalities of the oral cavity that patients who have an abnormality are amounted to $20 \%$ and patients who have more than one kind of oral abnormalities amounted to $80 \%$. An abnormality of the oral cavity that the most often found in this study is xerostomia with hyposalivation. Conclusion: Clinical feature of the oral cavity in patients with non-Hodgkin 's lymphoma whose underwent chemotherapy are abnormalities in the oral cavity, where the number of samples that experienced more than one type of oral cavity abnormality was greater when compared to the number of samples with a kind of abnormality. Oral cavity. Most of the samples studied had oral cavity abnormalities in the form of serostomia accompanied by hyposalivation.

Keywords: Abnormality of oral cavity, chemotherapy, lymphoma non-Hodgkin's.

\section{INTRODUCTION}

Lymphomas are uncontrolled growth of lymphoid cells that occur in lymphoid and reticuloendothelial tissue. These tumors are heterogeneous, characterized by common abnormalities of enlarged lymph glands followed by splenomegaly, hepatomegaly, and bone marrow abnormalities. These tumors can also be found extranodal which is outside the lymphatic system and lymphoid tissue in several organs, including the digestive tract, lung, skin, and other organs. Lymphomas are classified into 4 stages based on the number and location of lymph nodes and extranodal tissue involved. 1,2,3 The etiology is still unknown, but there are several factors that are thought to cause lymphoma, including 
immunodeficiency caused by Epstein-Barr virus infection, HIV, Psoriasis, Hepatitis C, Human T-cell Lymphotropic Virus-I (HTLV-I), Human Herpes Virus 8 (HHV 8), Helicobacter pylori; Hereditary immunodeficiency such as ataxia teleangiectasia; autoimmune disease; environmental factors (exposure to chemicals and radiation) and genetic factors. ${ }^{4,5,6,7}$

The Indonesian Medical Oncology Hematology Coordination and Cooperation Agency (BAKORNAS HOMPEDIN) states that the incidence of lymphoma is higher than leukemia and ranks the third fastest growing cancer after melanoma and lung. About $53 \%$ of blood malignancies that occur each year are lymphomas. The incidence of lymphoma has a 3-4\% increase every year. NonHodgkin type lymphoma (NHL) five times more than lymphoma of Hodgkin type lymphoma (HL). About 95 percent of NHL type lymphomas occur in adults and 5 percent in children. ${ }^{8}$

$\mathrm{NHL}$ is a type of cancer that responds to chemotherapy. Chemotherapy is the use of cytotoxic agents to destroy and inhibit the spread of rapidly multiplying cancer cells. Cancer is a pathological condition where there is an imbalance between the process of division and cell death. In this condition, the rate of cell division is much faster than cell death. Chemotherapy agents can be divided into several groups includingalkalking agents, antimetabolites, vinca alkaloids, antibiotic antitumor, topoisomerase inhibitors, platinum derivatives, tubulin poisons, and antibiotics.5,9,10 Chemotherapeutic agents which are generally used for sufferers of $\mathrm{NHL}$ include types of alkilators, antitumor antibiotics, vinca alkaloids, and hormonal agents. ${ }^{11,12}$

In general, chemotherapy has the potential to cause damage and toxicity effects. Systemic effects that occur due to chemotherapy agents usually include hair loss, nausea, vomiting, diarrhea, constipation, and bone marrow depression. Chemotherapy also has adverse effects on the oral cavity including mucositis, microorganism infections, bleeding and xerostomia. ${ }^{12}$ About $40 \%$ of all patients who receive chemotherapy experience complications in the oral cavity. This type of malignancy is closely related to the occurrence of oral cavity complications due to therapy. In general, hematologic malignancies such as leukemia and lymphoma cause bone marrow depression and tend to have a high frequency of causing oral complications..$^{9,13}$ Complications caused by chemotherapy can influence and determine the success of chemotherapy. Complications such as mucositis that cause pain, oral cavity bleeding, periodontitis and serostomia make it difficult for sufferers to eat, communicate, and maintain oral hygiene so as to worsen the patient's general health. ${ }^{10,14}$

Oral hygiene is a matter that must be considered during the chemotherapy because it can increase the risk of oral complications. In fact, many patients with hematological malignancies such as lymphoma still neglect oral hygiene. This is an important consideration for treating doctors and dentists to always maintain the patient's oral hygiene and provide education about the importance of maintaining oral hygiene during chemotherapy. ${ }^{12,13,15}$

In some patients oral complications can be asymptomatic. This complication, if left unchecked, can develop into more serious, even life-threatening patients. Clinicians should not only focus on cancer treatment but must also pay attention to complications that occur due to the administration of chemotherapy agents because they can affect the course of chemotherapy and the quality of life of patients..$^{12,16,17}$ The purpose of this study was to determine the clinical picture of the oral cavity of patients with non-Hodgkin's lymphoma who were undergoing chemotherapy at the Internal Medicine Department of Hasan Sadikin Hospital in the December 2011-January 2012 period.

\section{METHODS}

This type of research is observational descriptive. The study population was nonHodgkin's lymphoma sufferers who were undergoing chemotherapy at the Hematology and Medical Oncology Outpatient Installation Division of Internal Medicine at Hasan Sadikin Hospital Bandung.

The study sample was taken by consecutive sampling method, where every patient who met the inclusion criteria was included in the study until a certain period of time so that the number of patients needed as a sample was fulfilled. ${ }^{18}$ 
The inclusion criteria were patients who had been diagnosed with Non-Hodgkin's Lymphoma and were confirmed by Anatomical Pathology, including recurrences, patients undergoing chemotherapy with the CHOP regimen at the Hematology and Medical Oncology Installation at Hasan Sadikin Hospital in Bandung, regardless of the number of cycles, the researcher examined the patient at least 1 week after giving chemotherapy. Patients aged over 14 years, sufferers have platelet counts above 50,000 108 / 6L, patients are willing to be observed and fill out questionnaires throughout the study by signing informed consent.

Exclusion criteria included patients who were taking drugs such as antihypertension, antidepressants, anticholinergics, and antihistamines, patients who had diabetes mellitus, patients who were undergoing chemoradiotherapy, patients who were not willing to be observed and filled out the research questionnaire by not signing informed consent.

\section{RESULTS}

This research was conducted for 1 month in the period December 2011 to January 2012 in the Department of Internal Medicine Hasan Sadikin Hospital Bandung and obtained a sample of $30 \mathrm{NHL}$ patients who met the criteria.

Table 1 shows that the number of $\mathrm{NHL}$ sufferers with female sex is greater than that of
Table 1 Distribution of Characteristics of NHL Patients by Gender, Age Group, Disease Stage, and Number of Chemotherapy Cycles

\begin{tabular}{|c|c|c|}
\hline Category & amount & $\%$ \\
\hline \multicolumn{3}{|l|}{ Gender } \\
\hline Male & 12 & 40.0 \\
\hline Female & 18 & 60.0 \\
\hline Total & 30 & 100.0 \\
\hline \multicolumn{3}{|c|}{ Age group (years) } \\
\hline $15-22$ & 4 & 13.3 \\
\hline $23-30$ & 4 & 13.3 \\
\hline $31-38$ & 3 & 10.0 \\
\hline $39-46$ & 6 & 20.0 \\
\hline $47-54$ & 5 & 16.7 \\
\hline $55-62$ & 8 & 26.7 \\
\hline Total & 30 & 100.0 \\
\hline \multicolumn{3}{|c|}{ Stage of disease } \\
\hline 1 & 3 & 10.0 \\
\hline II & 17 & 56.7 \\
\hline III & 8 & 26.7 \\
\hline IV & 2 & 6.6 \\
\hline Total & 30 & 100.0 \\
\hline \multicolumn{3}{|c|}{ Number of chemotherapy cycles } \\
\hline $\mathrm{Ke}-1$ & 5 & 16.7 \\
\hline Ke-2 & 7 & 23.3 \\
\hline $\mathrm{Ke}-3$ & 2 & 6.7 \\
\hline $\mathrm{Ke}-4$ & 8 & 26.7 \\
\hline Ke-5 & 7 & 23.3 \\
\hline Ke-6 & 1 & 3.3 \\
\hline Total & 30 & 100.0 \\
\hline
\end{tabular}

Table 2 Distribution of NHL Patients Based on Hematological Status

\begin{tabular}{lllllllll}
\hline \multirow{2}{*}{ Category } & \multicolumn{3}{c}{$\mathrm{Hb}$} & $\mathrm{H}$ & \multicolumn{2}{c}{ Leukocytes } & \multicolumn{2}{c}{ Platelets } \\
\cline { 2 - 9 } & $\mathrm{L}$ & $\%$ & $\%$ & $\%$ & $\mathrm{~N}$ & $\%$ & $\mathrm{~N}$ & $\%$ \\
\hline$<$ Score normal & 8 & 26.7 & 10 & 33.3 & 10 & 33.3 & 6 & 20.0 \\
Score normal & 22 & 73.3 & 20 & 66.7 & 18 & 60.0 & 19 & 63.3 \\
$>$ Score normal & 0 & 0 & 0 & 0 & 2 & 6.7 & 5 & 16.7 \\
amount & 30 & 100.0 & 30 & 100.0 & 30 & 100.0 & 30 & 100.0 \\
\hline
\end{tabular}

Information:

$\begin{array}{ll}\mathrm{L}: \text { Male } & \\ \mathrm{P}: \text { Female } & \\ \mathrm{N}: \text { Amount } & : \text { Male: } 14,0-18,0(\mathrm{~g} / \mathrm{dL}) \\ \text { Score normal Hb } & : \text { Female: } 12,0-16,0(\mathrm{~g} / \mathrm{dL}) \\ & : 5000-10000 / 7 \mathrm{~L} \\ \text { Score normal leukocytes } & : 150000-400000 / 7 \mathrm{~L} \\ \text { Score normal platelets } & \end{array}$




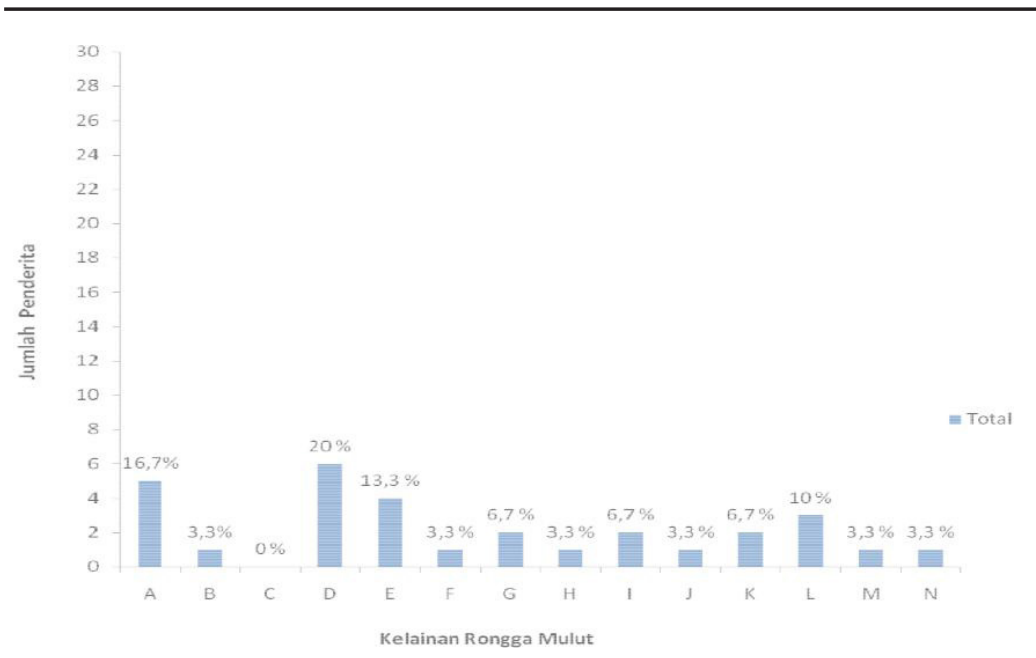

Information : $\mathrm{A}=$ Xerostomia; $\mathrm{B}=$

Periodontitis; $C$ = Mucosa bleeding; $D$

= Xerostomia and Hyposalivation; $\mathrm{E}$

$=$ Xerostomia and Periodontitis; $F$ =

Petekie and Periodontitis; $\mathrm{G}=$ Petechiae,

Xerostomia and Periodontitis; $\mathrm{H}=$

Ecchymosis, Xerostomia and Hyposalivation;

I= Xerostomia, Hyposalivation, and

Periodontitis; $\mathrm{J}=$ Mucositis, petechiae and

periodontitis; $\mathrm{K}=$ Mucositis, Xerostomia and

periodontitis; L= Mucositis, Xerostomia,

hyposalivation and periodontitis;

$M=$ Mucositis, Petechia, Xerostomia,

Hyposalivation and Periodontitis

Diagram 1 Prevalence of Mouth Cavity in NHL Patients

Table 3 Distribution of Oral Cavity Abnormalities by Age

\begin{tabular}{ccccccccccc}
\hline Group & & $\mathrm{A}$ & \multicolumn{2}{c}{$\mathrm{B}$} & & & $\mathrm{C}$ & \multicolumn{2}{c}{$\mathrm{D}$} & \multicolumn{3}{c}{$\mathrm{E}$} \\
\hline Age (year) & $\mathrm{N}$ & $\%$ & $\mathrm{~N}$ & $\%$ & $\mathrm{~N}$ & $\%$ & $\mathrm{~N}$ & $\%$ & $\mathrm{~N}$ & $\%$ \\
\hline $15-22$ & 2 & 25.0 & 1 & 14.28 & 4 & 14.8 & 3 & 23.0 & 3 & 16.8 \\
$23-30$ & 2 & 25.0 & 1 & 14.28 & 4 & 14.8 & 2 & 15.4 & 2 & 11.1 \\
$31-38$ & 1 & 12.5 & 1 & 14.28 & 3 & 11.1 & 2 & 15.4 & 1 & 5.5 \\
$39-46$ & 1 & 12.5 & 1 & 14.28 & 6 & 22.2 & 2 & 15.4 & 3 & 16.8 \\
$47-54$ & 1 & 12.5 & 2 & 28.57 & 4 & 14.8 & 3 & 23.0 & 3 & 16.8 \\
$55-62$ & 1 & 12.5 & 1 & 14.28 & 6 & 22.2 & 1 & 7.6 & 6 & 33.3 \\
\hline Value & 8 & 100.0 & 7 & 100.0 & 27 & 100.0 & 13 & 100.0 & 18 & 100.0 \\
\hline
\end{tabular}

Information: A = mucositis; $\mathrm{B}$ = submucosal bleeding; C = xerostomia; $\mathrm{D}$ = hyposalivation; $\mathrm{E}$ = periodontitis

Table 4 Distribution of oral cavity disorders based on gender

\begin{tabular}{cccccccccccc}
\hline Type & \multicolumn{1}{c}{ A } & B & & & C & \multicolumn{2}{c}{ D } & E \\
\hline Gender) & N & $\%$ & N & $\%$ & N & $\%$ & N & $\%$ & N & $\%$ \\
\hline Male & 1 & 12.5 & 3 & 42.85 & 11 & 40.7 & 4 & 30.8 & 6 & 33.3 \\
Fenale & 7 & 87.5 & 4 & 57.15 & 16 & 59.3 & 9 & 69.2 & 12 & 66.7 \\
\hline Amount & 8 & 100.0 & 7 & 100.0 & 27 & 100.0 & 13 & 100.0 & 18 & 100.0 \\
\hline
\end{tabular}

men. The number of female sufferers is 18 people $(60 \%)$ and male sufferers are 12 people $(40 \%)$. Distribution of NHL patients by age group, the highest prevalence occurred in the age group 5562 years as many as 8 people $(26.7 \%)$ while the least prevalence was the age group 31-38 years as many as 3 people (10.0\%). Distribution of NHL patients based on the stage of the disease, the highest prevalence was found in patients with stage II as many as 17 people (56.7\%) and the least prevalence was stage IV as many as 2 people (6.6\%). Distribution of NHL patients based on the amount of chemotherapy that has been done, the highest prevalence is found in patients with
4 cycles of chemotherapy as many as 8 people $(26.7 \%)$ and the least prevalence is in patients with 6 cycles as much as 1 person (3.3\%).

Table 2 shows that of all samples, 18 people had below normal hemoglobin values, 10 people (33.3\%) had leukocyte counts below normal and 6 people $(20.0 \%)$ had platelet values below normal.

Diagram 1 shows that there are various kinds of abnormalities in the oral cavity of patients with NHL. Patients who experienced one type of disorder totaled 6 people $(20 \%)$ while those who experienced more than one type of disorder totaled 24 people $(80 \%)$. The highest number is sufferers with xerostomia accompanied 
Table 5 Distribution of Oral Abdominal Disorders by Stage of Disease

\begin{tabular}{ccccccccccc}
\hline Stadium & & $\mathrm{A}$ & \multicolumn{1}{c}{$\mathrm{B}$} & \multicolumn{2}{c}{$\mathrm{C}$} & \multicolumn{2}{c}{$\mathrm{D}$} & \multicolumn{1}{c}{$\mathrm{E}$} \\
\hline & $\mathrm{N}$ & $\%$ & $\mathrm{~N}$ & $\%$ & $\mathrm{~N}$ & $\%$ & $\mathrm{~N}$ & $\%$ & $\mathrm{~N}$ & $\%$ \\
\hline I & 1 & 12.5 & 0 & 0 & 3 & 11.1 & 3 & 23.0 & 3 & 16.7 \\
II & 6 & 75.0 & 4 & 57.14 & 16 & 59.2 & 6 & 46.2 & 2 & 11.1 \\
III & 1 & 12.5 & 2 & 28.57 & 7 & 26.0 & 2 & 15.4 & 1 & 5.5 \\
IV & 0 & 0 & 1 & 14.28 & 1 & 3.7 & 2 & 15.4 & 3 & 16.7 \\
\hline Amount & 8 & 100.0 & 7 & 100.0 & 27 & 100.0 & 13 & 100.0 & 18 & 100.0 \\
\hline
\end{tabular}

Table 6 Distribution of Oral Abdominal Disorders by Number of Cycles of Chemotherapy

\begin{tabular}{ccccccccccc}
\hline Amount & & $\mathrm{A}$ & $\mathrm{B}$ & & \multicolumn{1}{c}{$\mathrm{C}$} & \multicolumn{2}{c}{$\mathrm{D}$} & \multicolumn{1}{c}{$\mathrm{E}$} \\
\hline Cycle & $\mathrm{N}$ & $\%$ & $\mathrm{~N}$ & $\%$ & $\mathrm{~N}$ & $\%$ & $\mathrm{~N}$ & $\%$ & $\mathrm{~N}$ & $\%$ \\
\hline 1 & 2 & 25.0 & 0 & 0 & 4 & 14.8 & 0 & 0 & 5 & 27.8 \\
2 & 1 & 12.5 & 3 & 42.85 & 6 & 22.2 & 1 & 7.7 & 5 & 27.8 \\
3 & 0 & 0 & 1 & 14.28 & 1 & 3.7 & 0 & 0 & 1 & 5.5 \\
4 & 4 & 50.0 & 1 & 14.28 & 8 & 30.0 & 5 & 38.4 & 5 & 27.8 \\
5 & 1 & 12.5 & 2 & 28.57 & 7 & 25.9 & 6 & 46.2 & 2 & 11.1 \\
6 & 0 & 0 & 0 & 0 & 1 & 3.7 & 1 & 7.7 & 0 & 0 \\
\hline Amount & 8 & 100.0 & 7 & 100.0 & 27 & 100.0 & 13 & 100.0 & 18 & 100.0 \\
\hline
\end{tabular}

Table 7 Distribution of mouth cavities based on oral hygiene index

\begin{tabular}{|c|c|c|c|c|c|c|c|c|c|c|}
\hline Cleanliness & & & & B & & C & & D & & $E$ \\
\hline Mouth & $\mathrm{N}$ & $\%$ & $\mathrm{~N}$ & $\%$ & $\mathrm{~N}$ & $\%$ & $N$ & $\%$ & $N$ & $\%$ \\
\hline Good & 0 & 0 & 1 & 14.3 & 8 & 29.7 & 5 & 38.5 & 0 & 0 \\
\hline Moderate & 3 & 37.5 & 4 & 57.1 & 9 & 33.3 & 3 & 23.0 & 8 & 44.4 \\
\hline Bad & 5 & 62.5 & 2 & 28.6 & 10 & 37.0 & 5 & 38.5 & 10 & 55.6 \\
\hline Amount & 8 & 100.0 & 7 & 100.0 & 27 & 100.0 & 13 & 100.0 & 18 & 100.0 \\
\hline
\end{tabular}

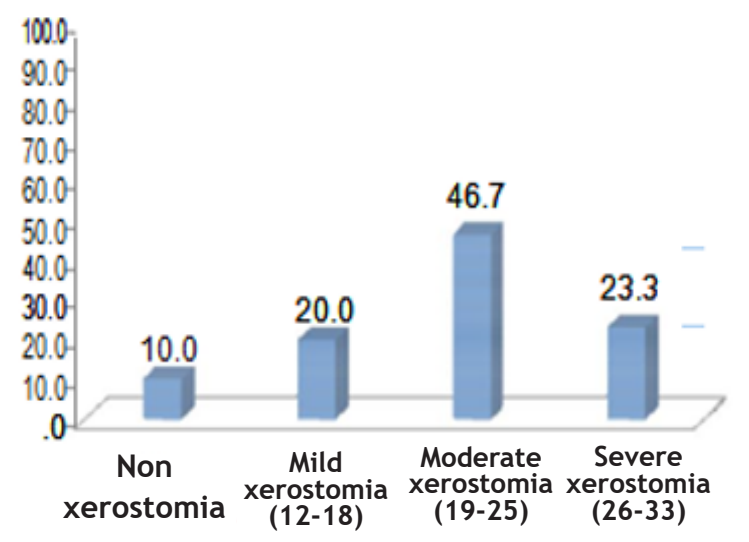

Diagram 2 Comparison of Xerostomia Severity in NHL Patients based on Xerostomia Inventory-Dutch version

by hyposalivation totaling 6 people (20\%).

The results of the study in Table 3 show that the highest number of mucositis occurs at ages 1522 years and 23-30 years, submucosal bleeding at

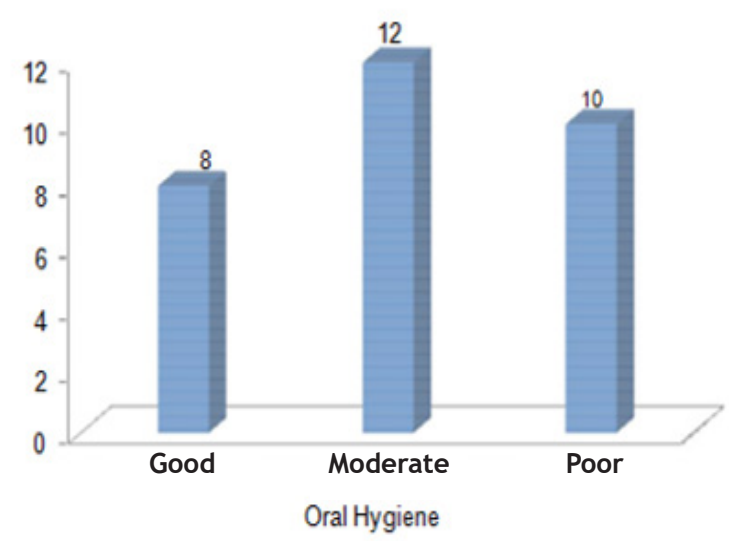

Diagram 3 Comparison of Oral Hygiene of NHL Patients

47-54 years of age, xerostomia at 39-46 years and 55-62 years, hyposalivation at $15-22$ years and 47-54 years and periodontitis at the age of 5562 years. The results in Table 4 show that there 
Table 8 Distribution Mucositis Based on WHO grading scale

\begin{tabular}{ccc}
\hline Severity Degree & N & $\%$ \\
\hline 0 & 22 & 73.3 \\
1 & 4 & 13.3 \\
2 & 4 & 13.3 \\
3 & 0 & 0 \\
4 & 0 & 0 \\
\hline Total & 100 & 30 \\
\hline
\end{tabular}

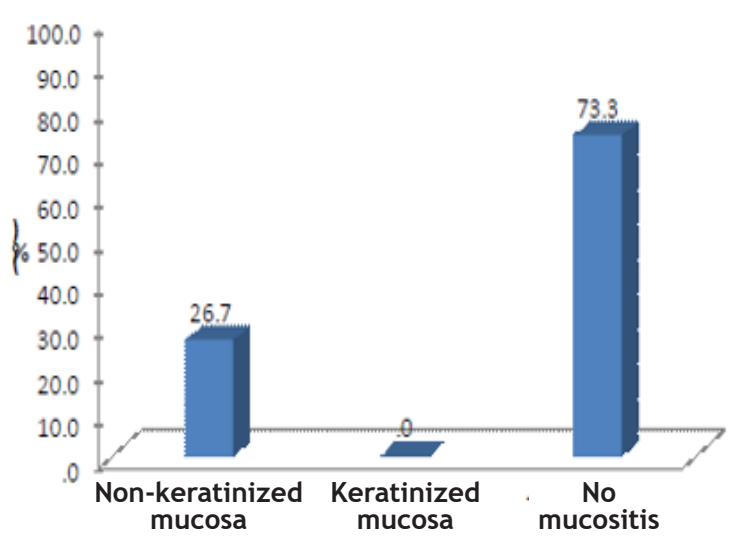

Diagram 4 Location Prevalence of Mucositis in NHL Patients

are clear differences in the number of mucositis, xerostomia, hyposalivation and periodontitis in the gender of women compared to men.

The results of the study in Table 5 show that there is a general increase in every type of oral disorders other than periodontitis in stage II, whereas in periodontitis no clear difference is found at each stage.

In Table 8, it can be seen the degree of severity of mucositis in NHL patients, namely mucositis with a degree of severity of 1 person (13.3\%) and mucositis with a degree of severity of 4 people $(13.3 \%)$. The results of the study in Diagram 4 show that mucositis that occurs in non-keratinous mucosa are 8 samples with a percentage of $26.67 \%$, mucositis in mucosa with keratin $0 \%$, and those without mucositis are 22 samples with a percentage of $73 \%$.

\section{DISCUSSION}

In this study, a sample of $30 \mathrm{NHL}$ sufferers with women (18\%) and 12 men (40\%) were sampled. The American Cancer Society in 2010 stated that there was a slight difference in the number of NHL cases based on sex where in general there were more in men than women, but in recent years the number of NHL cases has increased especially in women.

The increase in cases of NHL in women is thought to occur due to psychological stress factors that are greater than men. Stress is a condition caused by internal and external demands (stimulus) that can be dangerous, out of control or exceed the ability of individuals so that individuals will react both physiologically and psychologically (response). ${ }^{19}$ Based on research conducted on animals by Valentino, R in 2010 from the Children's Hospital of Philadelphia, researchers found that female mice are more sensitive to the stressrelated hormone corticotropin-releasing factor (CRF). Valentino, $\mathrm{R}$ and other research colleagues who stated that this study has the potential to have relevance to humans, because CRF is a characteristic of the occurrence of stress that is associated with mental disorders. The results of this study state that female mice are twice as susceptible to stress as male mice. In women, brain cells are more sensitive to CRF and have a low ability to adapt to large amounts of CRF whereas in male brains under stress, a number of hormone receptors can adapt so that the brain becomes unreactive to CRF. ${ }^{20}$ In addition, the hormone estrogen also influences the brain's response to stress. ${ }^{21}$ Prolonged (chronic) stress can weaken the immune system thereby increasing the risk of developing cancers associated with viral infections such as NHL. ${ }^{19}$

Based on Table 1, NHL was most commonly found at the age of 55 to 62 years $(26.7 \%)$ and at the age of 39 to 46 years (20.0\%). This condition is in accordance with the literature which states that $\mathrm{NHL}$ usually occurs in adulthood with an age range between 45 to 60 years. ${ }^{2}$. From the results of the above research it can be said that NHL is mostly found in the productive age and old adulthood. This is thought to occur because at a productive age the potential to be exposed to sun exposure, radiation and chemicals is higher than other ages. Then the stress factors, smoking and drinking alcohol which is a risk factor for NHL generally occurs a lot in the productive age.

The results also showed an increase in the number of NHL cases at the age of 55-62 years. A literature states that the risk factors for NHL increase with age, especially at the 
age of 60 years and over. ${ }^{22}$ This is thought to be due to decreased immune system function that occurs in old adulthood, including decreased antibody response to alloantigens, increased autoantibodies, decreased number of $\mathrm{T}$ cell responses and decreased $T$ cell proliferation capacity. Alcohol use and long-term consumption of cigarettes can also a factor that increases the risk of NHL. ${ }^{23}$ Nutritional factors can play a role in the occurrence of NHL such as intake of less nutritious foods can reduce endurance.

Based on Diagram 1, the most common oral abnormality is patients with xerostomia with hyposalivation $(20 \%)$. The occurrence of xerostomia is related to hyposalivation due to a disruption in the salivary glands due to chemotherapy agents, which causes the amount of saliva to decrease and change its chemical composition. Salivary consistency becomes thick, loses the function of lubrication so that the mouth becomes dehydrated. This condition can cause a burning sensation in the oral cavity. This is due to reduced lubrication. Xerostomia causes discomfort in patients, difficulty swallowing, chewing and talking, loss of sensation, anorexia and can cause weight loss. Decreased salivary secretion can also cause the formation of accumulation of bacteria, plaque and calculus thereby increasing the possibility of caries and periodontal disease, oral mucosa is easily injured and vulnerable to infection. ${ }^{24}$

Psychological factors such as depression, anxiety, stress or fear can also cause xerostomia. ${ }^{25}$ This is because the emotional state stimulates the sympathetic influence of the autonomic nervous system and prevents the parasympathetic system from causing salivary secretions. ${ }^{26}$ In this study found 27 people experienced xerostomia (90\%) and 13 people accompanied by hyposalivation (43.3\%). This condition is consistent with the literature which says that although most xerostomic patients experience hyposalivation, some do not. ${ }^{27}$ Xerostomia is suspected in patients who do not experience hyposalivation caused by psychological factors.

In this study, a higher number of xerostomia was found in the 39-46 years and 55-62 years age groups compared to other age groups (Table $3)$. Xerostomia is related to age because along with increasing age, there is an aging process in which changes and deterioration in the function of the salivary glands, the parenchymal glands are replaced by fat tissue, intermediate duct cell lining undergoes atrophy. This situation results in a reduction in the number of salivary flow ${ }^{26}$ (Hasibuan, 2002). Literature also states that the number of cases of xerostomia will increase with age where this condition is associated with increasing age, the risk of systemic disease and the use of drugs that cause xerostomia is increasing. In addition, other factors such as nutritional deficiencies can also cause xerostomia. ${ }^{25,28}$ In this study patients who had systemic abnormalities such as diabetes and taking drugs such as antihypertension, antidepressants, anticholinergics, and antihistamines were excluded to reduce bias. An increase in the number of xerostomia at the age of 39-46 years is thought to occur due to bad habits such as smoking. Nicotine contained in cigarettes at high concentrations can cause inhibition of salivary secretion resulting in xerostomia. ${ }^{29}$

Literature states that complaints of oral dryness (xerostomia) which are subjective are more common in women and are associated with psychological factors ${ }^{30}$ (Scully, 2003). In Table 4 it can be seen that the amount of xerostomia and hyposalivation is higher in women compared to men. This is thought to occur due to the influence of psychological factors where women are twice more susceptible to stress than men. ${ }^{20}$ In addition, disruption of reproductive cells caused by the CHOP chemotherapy regimen causes a decrease in the hormone estrogen. Esterogen is a steroid hormone that has receptors in the salivary glands and oral mucosa, so it can play a biological role in the oral mucosa and salivary glands (Joenoes, et al., 2007; Slim and Thomas, 2009). Estrogen hormone plays a role in the production of saliva so that the decrease in the hormone estrogen causes a reduction in the amount of saliva produced and changes in its composition. ${ }^{11,31}$

Diagram 2 shows the severity of xerostomia that occurs in patients with NHL lymphoma, where xerostomia with moderate severity is the highest number, $46.7 \%$. This is presumably because the doxorubicin chemotherapy agent given to $\mathrm{NHL}$ sufferers is one of the chemotherapy agents that can destroy salivary gland cells so that it has great potential in causing xerostomia. The sample in this study were patients who had received at 
least one cycle of chemotherapy, which in general during the study, the patient had received a chemotherapy agent 21 days before. Based on the literature, salivary gland damage occurs after administration of certain chemotherapy agents where the damage generally occurs 3 weeks after drug administration and is temporary. ${ }^{12}$

Periodontitis begins with the accumulation of plaque and calculus in the oral cavity. Plaque and calculus can increase the risk of local and systemic infections so that the accumulation of plaque and calculus must be minimized. It should be noted that patients who receive chemotherapy often have chronic oral infections such as periodontitis which can develop into more serious infections when the patient is in immunosuppressed conditions. Immunosuppressive conditions due to chemotherapy agents weaken the patient's immune system due to the destruction of platelets, leukocytes and erythrocytes; therefore the maintenance of oral hygiene needs to be considered to minimize the occurrence of infection and prevent more fatal complications. Therapy and evaluation of the oral cavity should be done before undergoing chemotherapy. In this study found 18 people experienced periodontitis $(60 \%)$ with $55.6 \%$ of all samples experiencing periodontitis having poor oral hygiene (Table 7). This condition is in accordance with the literature which states that periodontitis is closely related to the accumulation of plaque and calculus in the oral cavity. ${ }^{17}$

In Table 3 it can be seen that the number of periodontitis increased in the 55-62 years age group. This condition can be caused because in old age the risk factors for loss of periodontal attachment and alveolar bone resorption are higher than in young age, but age factors do not affect periodontitis singly, other factors such as systemic disease and oral hygiene are needed. ${ }^{32}$

The results in Table 4 show that periodontitis is more common in women than men. This condition is related to the decline in the hormone estrogen due to disruption of reproductive cells. Estersogens have a protective effect on bone and prevent overall bone loss. Estrogen deficiency causes a reduction in bone mineral density in the body which will increase the risk of alveolar bone resorption and chronic periodontitis. Reduced bone mineral density can also cause loss of periodontal ligament attachment where this condition will cause tooth sway. ${ }^{33}$

Based on history taking, there are 20\% of samples that brush teeth $\leq 1$ days and $80 \%$ of samples brush teeth $\geq 2$ times a day, but the number of patients with moderate and bad oral hygiene is still quite large, namely $40 \%$ and $33 \%$ of all samples. This is thought to have occurred due to improper tooth brushing techniques.

Mucositis can occur in patients who are undergoing chemotherapy. Mucocytis occurs as a result of the work of chemotherapy agents that damage cancer cells, where these cells divide very quickly, but chemotherapy agents are not selective so that they damage normal cells of the body that have rapid division time, one of which is oral epithelial cells. The direct inhibitory effect on DNA replication and proliferation of cellular mucosa by chemotherapy agents causes a reduction in the renewal capacity of basal epithelial cells so that the oral mucosal epithelial cells continue to thin out and cause mucositis. Mucositis usually forms on the 7th day to the 14th day after administration of chemotherapy agents. Mucositis is usually accompanied by pain, odor and necrotic tissue debris. The healing process begins at 2 to 4 weeks after therapy. In this study obtained patients who experienced mucositis as many as 8 people (3.3\%). This condition is consistent with the literature which states that standard chemotherapy regimens for NHL clinically give rise to significant oral mucositis in around 3\% $-10 \%$ of patients. ${ }^{34,35,36}$

Mucosal surface of the oral cavity has a rate of cell division that is different from other cells, which is between 4-5 days for non-keratinous mucosa and 14 days for keratinous mucosa. Epithelial cell progenitors which have a faster rate of division have a higher potential to suffer damage due to chemotherapy and radiotherapy, where the epithelial cell division process is faster than the old age so mucositis is more common at a young age. The results of the study in Table 3 show that the number of mucositis increased at a young age of 15-22 years and 23-30 years. The mucositis found in the study in Diagram 4 appears to be entirely in the non-keratinized mucosa. This condition is consistent with the literature which states that mucositis generally occurs in nonkeratinous oral mucosa such as labial mucosa, 
buccal, ventral tongue, floor of mouth and soft palate. ${ }^{11,35}$

In Table 4 it can be seen that mucositis is mostly found in women. The CHOP regimen has the potential to cause dysfunction in reproductive cells because these cells have a fast division rate. Disruption of reproductive cells in women causes decreased estrogen production. Estrogen hormone has a role in regulating cell growth, differentiation and function in reproductive and non-reproductive tissues including epithelial cells of the oral mucosa. In the oral epithelium there are B-type esterogen receptors, the presence of these receptors shows that the esterogen directly regulates the physiology of the oral tissue by binding to the estrogen receptor. If the estrogen hormone decreases, the maturation process of oral epithelial cells will also be disrupted. Epithelial cells will become thin and atrophy. ${ }^{11,31}$

Table 7 shows the highest number of mucositis occurring in patients with poor oral hygiene, which is $62.5 \%$ of all samples that have mucositis. This condition is in accordance with the literature which states that poor oral hygiene increases the risk of oral complications during therapy using cytotoxic agents including mucositis, ${ }^{35}$ Mucositis with a severity value of 2 was found in 4 samples and a severity value in 1 was 4 in accordance with those listed in Table 4.8. Oral mucositis begins to form on days 7 to 14 after chemotherapy and the healing process begins to occur 2 to 4 weeks after therapy. The study was conducted in the 3 rd week after administration of the chemotherapy agent where if the mucositis was formed in the sample it was already in the healing process so that the study did not find mucositis with the severity of 3 and 4 .

Blood-forming cells have a rapid rate of division so they are vulnerable to the effects of chemotherapy agents. Disruption of the bone marrow causes a reduction in the formation of erythrocytes, leukocytes and platelets so that the patient experiences anemia, leukopenia and thrombocytopenia. Bleeding in the oral cavity can occur during the period of chemotherapy associated with the condition of thrombocytopenia and can arise in the mucosa or submucosa. Mucosal bleeding usually occurs on the lips of the tongue and gums when the platelet count falls below $20,000 \mathrm{~mm} 3$. Submucosal bleeding can happen in the form of petechiae or ecchymosis.

In this study, ecchymosis was found in 1 sample (3.3\%) and petechiae in 6 samples $(20 \%)$ this number was not much different from the number of patients who had platelet values below normal (Table 2). This condition is consistent with the literature which states that mucosal and submucosal bleeding is an indirect stomatotoxicity due to thrombocytopenia. In this study, there were no patients who experienced spontaneous bleeding in the oral mucosa because none of the samples had platelet counts below 20,000 mm3. This condition can be caused because the majority of the samples studied are mostly in stage II (Table 4.1), whereas severe thrombocytopenia occurs at an advanced stage where bone marrow is involved. Thrombocytopenia usually occurs 7-10 days after administration of the chemotherapy agent then the megakaryocyte cell progenitor will begin to release platelets into the blood circulation on the 4th day and the platelet value will return to normal on the 7th day. Provision of chemotherapy can then be done if the platelet value is at least 100,000 / 7L. In this study platelet values were taken on the 21st day after the last chemotherapy so no samples with platelet values below 100,000 / 7L were found. In Tables 4.3 and 4.4 there are no clear differences in numbers based on age and

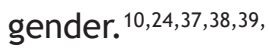

Based on Table 5 it can be seen that there is no significant difference in the number of oral cavity abnormalities in the stage of disease progression. In general the largest number was found in stage $\mathrm{II}$, this is thought to occur because most of the samples in the study (56.7\%) experienced NHL stage II.

Complications of the oral cavity that occur in the chemotherapy period are closely related to patient factors and therapeutic factors. Therapeutic factors consist of the chemotherapy agent used, dosage, and frequency of drug administration. Chemotherapy agents used in NHL sufferers are a combination of cyclophosphamide, vincristine, doxorubicin and prednisone (CHOP) where these agents have the potential to cause damage to the oral cavity epithelium, bone marrow and minor salivary glands but CHOP toxicity is lower than other regimens such as ACVBP (cyclophosphamide, doxorubicin, vindensine, bleomycin, prednisone) and DHAP (dexamethason, 
high dose Ara-C, cisplatin). Doses used for the treatment of $\mathrm{NHL}$ are cyclophosphamide $750 \mathrm{mg} /$ $\mathrm{m}^{2}$, doxorubicin $50 \mathrm{mg} / \mathrm{m}^{2}$, vincristine $1.4 \mathrm{mg} /$ $\mathrm{m}^{2}$ and prednisone $60 \mathrm{mg} / \mathrm{m}^{2} .{ }^{40}$

Based on Table 6 in general the number of mucositis, xerostomia and hyposalivation increases in the 4th and 5th cycles of chemotherapy. This condition is consistent with the literature which states that long-term use of cytotoxic agents (repetition of cycles) is associated with an increased risk of abnormalities in the oral cavity where the total dose of chemotherapeutic agents entering the body gets higher. ${ }^{24,35}$ In submucosal hemorrhage there is no clear difference in the number of each cycle increase. This condition is thought to be caused because at the time of recording, the platelet value had returned to its normal value because it was done 21 days after administration of chemotherapy. In periodontitis also not found a significant increase in the number of cycles. This thought to occur because periodontitis is strongly influenced by the cleanliness of the oral cavity of the patient, besides that age and gender factors also influence. ${ }^{24}$

\section{CONCLUSION}

Clinical feature of the oral cavity in patients with non-Hodgkin's lymphoma whose underwent chemotherapy are abnormalities in the oral cavity, where the number of samples that experienced more than one type of oral cavity abnormality was greater when compared to the number of samples with a kind of abnormality. Oral cavity. Most of the samples studied had oral cavity abnormalities in the form of serostomia accompanied by hyposalivation.

\section{REFERENCES}

1. Benvie. 2010. Limfoma non-hodgkin. Available at: http://doctorology.net/?p=380 (diakses tanggal 16 Mei 2011).

2. Mohan, H. 2005. Essential Pathology for Dental Students. $3^{\text {rd }}$ Ed. New Delhi:

1. Jaypee Brothers Med Publishers. 520,5245,532 pp.

3. Markus R; John W.S; and Michael E.W. 2007. Lymphoma Pathology, Diagnosis and Treatment. New York : Cambridge University Press.

\section{3,6-11,25 pp}

4. Marcucci, F and M. Alfonso 2010. Hepatitis viruses and non-hodgkin lymphoma: epidemiology, mechanism of tumorigenesis and therapeutic opportunities. Blood 117(6):1792-1798. Available at: http://bloodjournal.hematology library.org/content/early/2010/10/19/blood2010-06-275818(diakses tanggal 11 Mei 2011).

5. Fauci, A.S; E. Braunwald; D.L. Kasper; S.L. Hauser; D.L. Longo; J.L. Jameson; and J. Loscalzo. (ed.). 2009. Harrison's Manual of Medicine. $17^{\text {th }}$ Ed. New York: The McGraw-Hills Companies. 340, 352-5, 358-9 pp.

6. Bower M; M. Fisher; T. Hill; I. Reeves; J. Walsh; C. Orkin; A.N. Phillips; L. Bansi; R. Gilson; P. Easterbrook; M. Johnson; B. Gazzard; C. Leen; D. Pillay; A. Schwenk; J. Anderseon; K. Porter; M. Gompels; and C.A. Sabin. 2009. CD4 counts and the risk of systemic non-hodgkin 's lymphoma in individual with HIV in the UK. Haematol 94 (6): 875-880. Available at: http:// www.haematologica.org/content/94/6/ 875 . full.pdf+html (diakses tanggal 13 Mei 2011).

7. Robert, S. 2006. Lymphoma risk in psoriasis: results of the PUVA follow-up study. Arch Dermatol 142:1132-1135. Available at: http://archderm.ama-assn.org/cgi/reprint/142/9/1132 (diakses tanggal 13 Mei 2011).

8. Felix. 2006. Sistem kekebalan tubuh itu justru mengganas. Farmacia 6 (5): 12.

2. Available at: http://www. majalah-farmacia.com/rubrik/one_news. asp?!D

3. News=374 (diakses tanggal 13 Mei 2011).

9. Baquiran, D.C. 2001. Cancer Chemotherapy Handbook. $2^{\text {nd }}$ Ed. Philadelphia: Lippincot. 3, $85 \mathrm{pp}$.

10. Yarbro, C.H; D, Wujcik; and B.H, Gobel. 2011. Cancer Nursing Principles and Practice. $7^{\text {th }}$ Ed. Sudbury : Jones and Bartlett Publishers. 4823, 466, 1463, $1473 \mathrm{pp}$.

11. DeVita, V.T. Jr; T. S. Lawrence; and S. A. Rosenberg. (ed.). 2008. DeVita Hellman \& Roosenberg Principles \& Practice of Oncology. $8^{\text {th }}$ Ed. 447-53,546, 2100, 2655-7 pp.

12. Yagiela, J.A; Frank, J.D; and Enid, A.N. 2004. Pharmacology and Therapeutics for Dentistry. $5^{\text {th }}$ Ed. St Louis: Mosby, Inc. 797-800 pp.

13. Sonis, S.T; Robert C.F; and Leslie F. 1995. Principles and Practice of Oral Medicine. $2^{\text {nd }}$ Ed. 
Philadelphia: WB Saunders Company. 426-447

14. Greenberg, M. S and M. Glick. (ed.). 2003. Burket's Oral Medicine Diagnosis \& Treatment. 10 $0^{\text {th }}$ Ed. Ontario: BC Decker Inc.

15. Seymour, R.A. 2010. Malignant Disease and the Delivery of Dental Care. Dent Update 37 (1): 20-2, 25-6. Available at: http://www. ncbi.nlm.nih.gov/ pubmed/20218458 (diakses tanggal 16 Mei 2011).

16. Fischer, D.J. 2008. Management of patient who have undergone head and neck cancer therapy. Dent Clin North Am 52 (1): 3960. Available at: http://www.mendeley. $\mathrm{com} /$ research/management-patients-undergone-head-neck-cancer-therapy/ (diakses tanggal 16 Mei 2011).

17. Wong, F. 2009. A survey of clinicians: prioritization of dental treatment in leukemia patient prior to chemotherapy. Int J Prosthodont 22(3): 303-6. Available at: http://www.dentalarticles.com/search/24.php (diakses tanggal 16 Mei 2011).

18. Sastroasmoro, S. 2002. Dasar-Dasar Metodologi Klinis. $2^{\text {nd }}$ Ed. Jakarta:

4. Perpustakaan Nasional RI: Katalog Dalam Terbitan. 80-85 pp.

19. Tawi, M. 2011. Konsep dasar tentang stress. Available at: http://syehaceh. wordpress. com/2011/08/22/konsep-dasar-tentangstress/ (diakses tanggal 22 Febuari, 2012).

20. Valentino, R. 2010. Stress hormone receptors less adaptive in female brain. National Institute of Mental Health. Available at: http:// www.nimh.nih.gov/ science-news/2010/ stress-hormone-receptors-less-adaptive-in-female-brain.shtml (diakses tanggal 22 Febuari 2012).

21. Boyles, S. 2003. Estrogen is involved in stress response. Available at: http://www. webmd. com/depression/news/20031203/estrogen-isinvolved-in-stress-response (diakses tanggal 21 Febuari 2012).

22. American Cancer Society. 2010. Non-hodgkin lymphoma. Available at: http:// documents. cancer.org/acs/groups/cid/documents/webcontent/003126-pdf.pdf (diakses tanggal 26 Desember 2011).

23. Morrison, V.A. 2002. Non-Hodgkin's Lymphoma in the Elderly. 277 pp. Available at: http:// web.squ.edu.om/med-Lib/MED_CD/E_CDs/
Malignant $\quad$ \%20Lymphomas/docs/ch16.pdf (diakses tanggal 11 Maret 2012).

24. Broadfield, L; J. Hamilton; and G. Sophie. 2006. Best practice guidelines for the management of oral complication from cancer therapy. Supportive Care Cancer Site Team, Cancer Care Nova Scotia. 49, 74 pp. Available at: http://www.cancercare.ns.ca/site-cc/ media/cancercare/Oral_Care DPV_FINAL.pdf (diakses tanggal 8 Mei 2011).

25. Bartels, C.L. 2001. Xerostomia information for dentist. Available online at: http:// oralcancerfoundation.org/dental/xerostomia.html (diakses tanggal 9 Januari 2012).

26. Hasibuan, S. 2002. Keluhan mulut kering ditinjau dari faktor penyebab, manifestasi dan penanggulangannya. Fakultas Kedokteran Gigi Sumatera Utara. 2-4 pp. Available at: http:// library.usu.ac.id/download/fkg/fkg-sayuti. pdf (diakses tanggal 10 Maret 2012).

27. Lukisari, C dan Kusharjanti. 2010. Xerostomia: Salah Satu Manifestasi Oral Diabetik. Available at:http://canelukisari.blogspot. com/2010/04/ xerostomiasalahhttp://professional.cancerconsultants.com/currentoncology.a spx?id=33386-satu-manifestasi-oral.html (diakses tanggal 17 Mei 2011).

28. Fox, P.C. 2008. Xerostomia: recognition and management. American Dental Hygienists' Association. 2 pp. Available at: http://www. adha.org/downloads /Acc0208Supplement. pdf (diakses tanggal 11 Maret 2008).

29. Collins, F.M. 2009. Tobacco cessation and the impact of tobacco use on oral health. 3-4 pp. Available at: http://chfs.ky.gov/ NR/rdonlyres/31D160F5-8270-4BB1-BB5FA4199108A499/0/TobaccoCessation.pdf(diakses tanggal 16 Maret 2012).

30. Scully, C. 2003. Drug effects on salivary glands: dry mouth. Oral Diseases 9 (10): 165176. Available at: http://onlinelibrary.wiley. com/doi/10.1034/j.1601-0825.2003.03967.x/ pdf (diakses tanggal 11 Maret 2012).

31. Valimaa, H; S, Savolainen; T, Soukka; P. Silvoniemi; S. Makela; H. Kujari; J.A. Gustafsson; and M. Laine. 2004. Estrogen receptor- $B$ is the predominant estrogen receptor subtype in human oral epithelium and salivary glands. J Endocrinol 180: 55-62. Available at: http://joe. endocrinology-journals.org/con- 
tent/180/1/55.full.pdf (diakses tanggal 19 Maret 2012).

32. Burt, B.A. 1994. Periodontitis and aging: reviewing recent evidence. J Am Dent Assoc 125

(3): 273-279. Available at: jada.ada.org/content/125 /3/273.abstract (diakses tanggal 11 Maret 2012).

33. Buencamino, M.C; L. Palomo; and H. L. Thacker. 2009. How menopause affects oral health, and what we can do about it. Cleveland Clinic Journal of Medicine 76 (8): 467-475. Available at: http://www.atlantadentalspa.com /articles/Perio_and_menopause.PDF (diakses tangaal 19 Maret 2012).

34. Epstein, J. B. 2007. Mucositis in the cancer patient and immunosuppressed host. Infect Dis Clin N Am 21:503-522. Available at: http:// linkinghub

35. Kostler, W.J; Michael, H; Catharina, W; and C. C. Zielinski. 2001. Oral mucositis complicating chemotherapy and/or radiotherapy: option for prevention and treatment. CA Cancer J Clin 51; 290-315. Available at: http:// onlinelibrary.wiley.com/doi/10.3322/canjclin. 51.5.290/pdf (diakses tanggal 17 Mei 2011).

36. Ilgenli, T; Hale, O; and Kamer, U. 2001. The acute effects of chemotherapy upon the oral cavity: prevention and management. Turk $J$ Canc 31(3): 94-9. Available at: http://www. turkjcancer.org/pdf/pdf TJC 36.pdf (diakses tanggal 27 Mei 2011)

37. Cairo, M.S. 2000. Dose reduction and delays: limitations of myelosupressive chemotherapy. Oncology 14 (8): 21-31. Available at: http://www. cancernetwork.com/display/article/10165/92613 (diakses tanggal 11 Maret 2012).

38. Kaushansky, K; E. Beutler; U. Seligsohn; M. Litchman; T.J. Kipps; and J. Prchal. (ed.). 2010. Williams Hematology. $8^{\text {th }}$ Ed. New York: MCGraw-Hill Companies, Inc. 1721 pp.

39. Tirgan, M.H. 2011. Thrombocytopenia. Available at: www.tirgan.com/thrpeniahtm (diakses tanggal 11 Maret 2012).

40. Tilly, H; E. Lepage; B. Coiffier; M. Blanch; R. Herbretch; A. Bosly; M. Attal; G. Fillet; C. Guettier; T. Molina; C. Gisselbretch; and F. Reyes. 2003. Intensive conventional chemotherapy (ACVBP regimen) compared with standard CHOP for poor-prognosis aggressive non-Hodgkin lymphoma. Blood 102: 42844289. Available at: http://bloodjournal.hematologylibrary. org/content/102/13/4284. full.pdf (diakses tanggal 17 maret 2012). 